\title{
Tuotemaailman umpikujasta luovuttamisen etiikkaan
}

\author{
Kilpailuyhteiskunnan \\ radikaali toisin kuvittelu
}

\begin{abstract}
$+y$
Luovuttamisen etiikka kehottaa ekologisesti ja sosiaalisesti kestämättömälle tuotemaailmalle ja kilpailuyhteiskunnalle vaihtoehtoiseen toimintaan. Kuluttamisen ja kilpailun sijaan esiin nousevat solidaarisuus ja rakkaus.
\end{abstract}

$\boldsymbol{y}$

KRIITTISTÄ TEORIAA LUONEET FILOSOFIT Max Horkheimer ja Theodor W. Adorno esittävät teoksessaan Valistuksen dialektiikka, että myöhäismodernissa yhteiskunnassa luonnon hallinnan menetelmistä tulee ihmisen hallinnan välineitä, ja lopulta ihmisen aseman voi päätellä siitä, mihin tilaan luonto saatetaan. (Horkheimer \& Adorno 2008, 22;32).

Kriittiseen teoriaan keskeisesti vaikuttaneet varhaisen Frankfurtin koulukunnan jäsenet vetosivat kirjailija Ferdinand Künbergerin lauseeseen ”Elämä ei ole elossa" (Adorno 1997, 13). He tulkitsivat sen niin, että kapitalismin kaikkialle tunkeva arvottaminen johti ainoastaan välinearvojen tunnustamiseen. Itseisarvojen tunnustamattomuus johti lopulta arvottomuuden tilaan, jossa sekä arvotettavat kohteet että niiden maailma ymmärrettiin vain välineiksi (Wiggershaus 1994, 5).

Kriittistä teoriaa edustaneen varhaisen Frankfurtin koulukunnan tavoite oli paljastaa vallitsevan järjestelmän talouden ja sosialisaation filosofiset taustaolettamukset, jotta välineellistävästä järjestelmästä olisi mahdollista vapautua. Kasvatuksen näkökulmasta kysymys on tilanteesta, jossa kasvattaminen ja itsekasvatus välineellistyvät tekniikoiksi saada aikaan työ- ja kulutuskykyä. Tällöin kasvatuksessa ei ole mahdollisuutta osoittaa hyötynäkökulmista ja välinearvoista riippumattomia merkityksiä.

Filosofi, taloustieteilijä ja psykoanalyytikko Cornelius Castoriadis (1997) on pohtinut yhteiskuntien 
MAGMAN TUNNISTAMINEN

\section{EDELLYTT $\dddot{A A ̈ ~ R A D I K A A L I A ~}$}

KUVITTELUA.

ja kulttuurien pysyvyyttä ja muutosta. Yhteiskunnat näyttävät yhtäältä vakailta ja yhtenäisiltä, mutta toisaalta yhteiskunnallisten ja kulttuuristen muutosten äkillisyys ja ennustamattomuus on yllättävää. Castoriadisin mukaan instituutiot pitävät yhteiskuntaa koossa. Esimerkiksi koululaitos, kirkot, laki pitävät yllä olemassa olevaa järjestystä, jonka mukaan yhteiskunnassa toimitaan ja järjestetään elämää. Instituutioiden tehtävät ja toisistaan poikkeavat intressit perustuvat yhteiskunnan kokonaisuuteen, jonka sisäinen koheesio perustuu monimutkaiseen merkityksien verkkoon. (Mt., 7.).

Castoriadis kutsuu merkitysten verkkoa 'sosiaalisen kuvittelun merkityksien magmaksi' (magma of social imaginary significations) (mt.). Hän ei juurikaan perustele magma-käsitteen käyttöä, mutta viitannee vertauskuvallisesti käsitteen geografiseen merkitykseen. Vakaalta vaikuttavan maan pinnan alapuolella on magmaa, joka on osittain sulan kiven ja erilaisten kaasujen kerros. Tulivuorenpurkauksissa magmaa purkautuu maan pinnalle. Tällöin sitä kutsutaan laavaksi.

Esimerkkejä sosiaalisen kuvittelun merkityksistä ovat muun muassa jumalat, Jumala, henget, kansalainen, puolue, hyödyke, pääoma. Castoriadis kutsuu merkityksiä kuvitteellisiksi, koska ne luodaan osaksi yhteiskunnan merkitysverkostoa. Magmalle ei ole vastineita tosi olevassa tai magman ulkopuolisessa rationaalisessa ajattelussa. Se on sosiaalisen kuvittelun luomus. Instituutioiden perustan luomisessa ei kuitenkaan voi ylittää jatkuvasti esimerkiksi ekologisia rajoitteita tai ihmisen perustarpeita (mt., 256).

Todellisuuden tuotteistamiseen ja kuluttamiseen keskittyneen tuotemaailman magma ilmenee esimerkiksi teknologisen kehityksen arvottamisena edistykseksi, kilpailuttamisen samaistamisena oikeudenmukaisuuteen ja tahdon korostamisena yksilön toiminnassa.
Jotta magma tunnistetaan ja sille voidaan luoda vaihtoehtoja, tarvitaan radikaalia kuvittelua. Se on kulloisenkin yhteiskunnan ontologisten, episteemisten ja moraalisten sitoumuksien paljastamista siten, että ne voidaan kuvitella toisin. Radikaalilla kuvittelulla voidaan paljastaa nykyistä magmaa ja kuvitella yhteiskunnan toiminnan vaihtoehtoista perustaa. Sen sijaan pelkkä luova kuvittelu on annetuissa lähtökohdissa pysyttelemistä, jolloin tuloksena voi toki olla uusia oivalluksia, mutta oivalluksista ei synny yhteiskunnallista magmaa muuttavaa ajattelua. (Mt.).

Tutkimme tuotemaailman magmaa metafyysisestä ja psykososiaalisesta näkökulmasta. Tuotemaailmalla filosofi ja aktivisti Günther Anders (2002a, 33) tarkoittaa tuotteista, niiden valmistamisesta ja kuluttamisesta muodostunutta todellisuutta. Tarkastelemme kriittisen teorian perinteestä nousevan ajattelun mahdollisuuksia luoda vaihtoehtoista sosiaalisten merkitysten verkkoa. Samalla tuomme esiin perusteita, joiden vuoksi inhimillistä toimintaa olisi järkevä perustaa kilpailuyhteiskunnan ohittamiin luovuttamisen merkityksiin.

Tuotemaailman esittely ja kilpailuyhteiskunnan kritiikki johdattavat hahmottamaan luovuttamisen etiikkaa, joka ottaa huomioon sen, että ihmisenkin olemassaolo ja toiminta perustuu muihin eliöihin, olioihin ja laajimmillaan biosfääriin. Tämän vuoksi esittelemme varhaisen Frankfurtin koulukunnan keskeisen filosofin Theodor W. Adornon negatiivista dialektiikkaa ja hänen aikalaisensa Günther Andersin kuvittelukyvyn laajentamisen ajatusta.

Luovuttamisen etiikka johdattaa käsittämään elämän relationaalisuutta ja eliöiden ainutlaatuisuutta, millä näkemyksemme mukaan on merkitystä hyvinvoinnin ekologista ja sosiaalista ulottuvuutta painottavalle (Salonen \& Bardy 2015) ekososiaaliselle sivistysajattelulle.

Ekososiaaliseen sivistysajatteluun kuuluu ihmisten keskinäisen riippuvuuden ja tasaveroisuuden sekä ekologisen eheyden ja monimuotoisuuden huomioiminen osana rauhaa ja demokratiaa (Salonen 2018). Perustelemme käsitteen 'etiikka' käyttöä sen alkuperäisellä merkityksellä: ethos viittaa tapaan elää ja asua, tapaan olla olemassa (Nancy 2007). 


\section{LUOVUTTAMINEN ON}

\section{KUULUMISTA JOHONKIN, \\ JONKA OLEMASSAOLO ON \\ VÄLTTÄM ÄTÖN JOHONKIN}

KUULUVALLE.

\section{LUOVUTTAMISEN KÄSITE}

'Luovuttaminen' on monimuotoinen käsite, jonka eri merkityksillä on ontologisia, kuvailevia ja eettisiä sivumerkityksiä.

Ensinnä luovuttaminen on antamista ja jättämistä jollekin. Kirjailija Markku Envallin (2010) mukaan "luovuttaminen on antamisen juhlallisempi muoto". Envallilta jäänee huomaamatta, että luovuttaminen on luovuttajalle jotain omakohtaista. Voin antaa sinulle makeisen, mutta makeisen luovuttaminen on outo tai juhlallinen ilmaisu. Luovuttaja antaa usein jotain elimellisesti häneen itseensä kuuluvaa, kuten verta, munuaisen, munasolun tai siittiöitä.

Toiseksi luovuttaminen on irti päästämistä. Esimerkiksi yliopiston tutkimusryhmä voi luovuttaa yleiseen käyttöön kehittämänsä hyvän elämän idean. Kolmanneksi luovuttamista on kilpailun kesken jättäminen: kun kilpailija lakkaa tavoittelemasta voittoa itselleen, hän antaa voiton jollekin toiselle. Luovuttaja voi kieltäytyä jatkamasta jotain toimintaa kokiessaan toiminnan jatkamisen mielettömyyden.

Myös biologinen symbioosi edellyttää luovuttamista. Kahden tai useamman olion välinen yhteiselämä ei onnistuisi, jos ne eivät luovuttaisi toisilleen ja saisi toisten luovuttamaa itselleen. Tässäkin mielessä luovuttaminen on jotain ylläpitävää, vaikka symbioottisen suhteen muodostavat olennot eivät toisiaan tiedostaisikaan kuten mutualismissa tapahtuu.

Nykyisin biologiassa ihmiset määritellään holobionteiksi eli useiden eliölajien muodostamiksi ekosysteemeiksi, joiden olemassaolo on mahdollinen vain usean eri organismin välisen symbioottisen toiminnan ansiosta. Ihmisyksilössä on toden- näköisesti enemmän muiden organismien kuin ihmisen soluja. (Aaltola \& Keto 2017, 238.) Esimerkiksi ilman suolistobakteerien ja kehon toimintojen välisiä luovuttamisprosesseja yhtään ihmistä ei olisi olemassa.

Itse asiassa biologisesti yksilön määritteleminen on ongelmallista, koska elämän prosessit ovat yhteen kietoutuneita (Skillings 2017). Kemiallisten reaktioiden olennainen ominaisuus on esimerkiksi elektronien luovuttaminen aineelta toiselle aineelle. Maapallon elämälle välttämättömän yhteyttämisprosessin reaktioissa kasvit luovuttavat happea ilmakehään. Kasvit taas ottavat käyttöönsä muiden eliöiden luovuttamaa hiilidioksidia.

Luovuttaminen on kuulumista johonkin, jonka olemassaolo on välttämätön johonkin kuuluvalle. Samalla luovuttaminen on jostain antamista - itsestä tai siitä, mihin kuuluu. Luovuttamisen toinen osapuoli saa luovuttamisessa jotain olennaisen tärkeää, jota ilman erityisesti elollisten ja sosiaalisten olentojen elämä olisi mahdotonta. Luovuttamisen prosesseissa ei kuitenkaan pyritä identifioimaan vastaanottajaa siten, että tämän asema märïttyisi luovuttajan tahdon mukaan. Vastaavasti luovuttaminen on luovuttajan olemassaolon jatkuvuudelle olennaista. Tässä merkityksessä luovuttaminen rikkoo näkemyksen eristetyistä yksilöistä, jotka kamppailevat olemassaolostaan resursseiksi pelkistetyssä maailmassa.

Hyve-etiikan termein luovuttamiseen liittyvät sellaiset hyveet, joihin sisältyy ajatus yhteisöllisyyden ja erityisyyden peruuttamattomasta arvosta. Yksilön irrallisuutta muusta todellisuudesta korostavan asenteen seurauksena ihminen luovuttaa vastentahtoisesti, mutta luovuttava anteliaisuus kumpuaa myös yhteisön elämää rikastavista arvoista. Luovuttaja voi olla esimerkiksi lahjoittaja, joka antaa itsestään elämälle tai jonkin hyvän jatkumiselle. Ja kääntäen luovuttaminen on lahjoittamista itsestä kokonaisuudelle, johon välttämättä kuuluu.

Luovuttamisen käsite ontologisessa merkityksessä viittaa yhtäältä elämän olemassaolon kannalta välttämättömiin biologisiin ja kemiallisiin prosesseihin. Toisaalta se kyseenalaistaa näkemyksen eliöyksilöstä selkeänä ja rajattuna yhden lajin ilmentymänä. Lisäksi luovuttamisen sosiaalinen merkitys 


\section{LUOVUTTAMISEN ERI}

\section{MERKITYKSI $\ddot{A}$}

EI VOIDA PALAUTTAA

TOISIINSA.

johdattaa tarkastelemaan yhteiskuntien ja yhteisöjen perustumista erilaisille luovuttamisen tapahtumille, kuten perinteen tai ideoiden synnyttämiselle ja jakamiselle.

Ihmisyksilöksi kasvaminen psykososiaalisessa merkityksessä on vuorovaikutusta, jota voidaan osittain kuvata luovuttamisen käsitteen avulla. Huolehtiva vanhempi luovuttaa varhaiskehityksen onnistumiselle välttämätöntä rakkautta ja huolenpitoa. Samalla hän itse kasvaa osaksi kiinteää vuorovaikutussuhdetta, jonka olemassaolo määrittää ratkaisevasti hänen merkityksellisyyden kokemuksiaan. Luovuttaminen moraalisena tekona voi liittyä esimerkiksi elämän jatkumisen kannalta välttämättömän elimen tai veren lahjoittamiseen toiselle. Yhteisö tai yksilö voi luovuttaa omistamansa metsäalueen suojeltavaksi, jotta vältetään metsän tuhoaminen.

Nähdäksemme luovuttamisen eri merkityksiä ei voida palauttaa toisiinsa. Esimerkiksi luovuttaminen moraalisena tekona ei ole riippuvainen luovuttamisen ontologisesta tai sosiaalisesta merkityksestä. Luovuttamisen eri merkitykset muodostavat kuitenkin toisiaan tukevan kokonaisuuden.

\section{TUOTEMAAILMAN METAFYSIIKKA: TALOUSONTOLOGIA}

Günther Andersin mukaan maapallon ekosysteemien ja ihmisten olemassaolon kannalta keskeinen kysymys on, kykeneekö ihminen luomaan tuotemaailmalle vaihtoehtoisia elämänmuotoja. Tuotemaailman syntymiselle keskeistä on ollut teknologinen kehitys, joka mahdollistaa yhä uusien olioiden haltuunoton osaksi tuotemaailmaa.
Sinänsä teknologia Andersin (2002c, 24) mukaan kuvastaa ihmisen kuvittelukykyä, jonka kasvattaminen on jäänyt tarpeettomasti unohduksiin. Yhteiskuntien toiminta perustuu lopulta tiettyihin peruskäsityksiin olemassaolon, olioiden ja niiden välisten suhteiden luonteesta. Ne muodostavat Castoriadisin mukaan yhteiskunnan magman.

Tuotemaailmassa vallitsevan talousontologian mukaan oleva on vain sarjavalmisteina ja hyödynnettävänä. Tuotemaailmassa todellisuus ilmenee hyödynnettävien tuotteiden riveinä ja sarjoina. Vastaavasti sen enempää ainutlaatuisella kuin hyödyttömäläkään ei ole olemassaolon oikeutusta. (Anders 2002a, 33).

Tuotemaailmassa oleva on tuotantoprosessin tulosta tai sen hyödynnettävissä. Tässä mielessä olevaa muokataan tuotantoprosessille kelvolliseksi. Samalla luonnon eliöiden ainutlaatuisuus tai ihmisen kasvuprosessin yksilöllisyys ei ole tunnistettavissa. Talousontologia oikeuttaa ainutlaatuisten eliöiden ja ekologisten alueiden käyttämisen pelkkänä raaka-aineena sarjavalmisteisten tuotteiden valmistamiseksi. Vastaavasti koulutuspolitiikassa korostuu koulutuksen välinearvo.

Talousontologinen oppi kyseenalaistaa sille vieraiden itseisarvojen ja instituutioiden oikeutuksen. Kasvatuksen historiaa tutkinut Mika Ojakangas $(2001,21)$ puhuu 'teknologisesta nihilismistä', joka perustuu hänen mukaansa uskoon luonnon ja ihmisluonnon läpikotaisesta muokkaamisesta. Arvoilla, jotka eivät kestä talousontologiaan perustuvaa tarkastelua, ei tuotemaailmassa ole merkitystä. Esimerkiksi sivistyksen perusteleminen kasvatuksen ja koulutuksen perustaksi on vaikeaa, mikäli sivistys viittaa yksilön ainutlaatuiseen ja yleisesti henkiseen kehitykseen (Ks. esim. Gadamer 1990, 19).

Tuotemaailmassa ihmisen toimintaa tarkastellaan suoritteina, joita voidaan verrata yhteismitallisina sarjoina. Kilpailuttamista oikeutetaan talousontologian mukaisesti osaamisen hyödynnettävyydellä, tehokkuuden maksimoinnilla ja uskolla markkinoiden hyvinvointia lisäävään voimaan. Ihminen identifioidaan kilpailusuoritukseensa, jota arvioidaan yhteismitallisilla suureilla, kuten tehokkuudella, nopeudella ja tuottavuudella. Kilpailuttaminen on tällöin menetelmä, 


\section{LAPLACEN DEMONI TIET Ä̈̈}

\section{KAIKKI UNIVERSUMIA}

\section{HALLITSEVAT LUONNONLAIT}

JA OLIOIDEN TARKAT

SIJAINNIT.

joka konkretisoi talousontologista oppia. Tässä merkityksessä se on samalla moraalinen oikeuttamisprosessi. Lopputulos on hyväksyttävä, koska sitä on edeltänyt oikeudenmukaiseksi väitetty prosessi. Kun suoritteet standardoidaan, ihmisen suorituskykyä verrataan koneen suorituskykyyn. Luonnossa esiintyvä moninaisuus, biodiversiteetti, muunnetaan sarjatuotteiksi, joiden tuotannon ja kuluttamisen ongelmiin vastataan kiihdyttämällä teknistuotannollista prosessia (von Wright 1999, 111).

Andersin näkemys lähestyy varhaisen Frankfurtin koulukunnan edustajien pessimistisiä ja synkkiäkin näkemyksiä myöhäismodernista ajasta. Anders kuitenkin kehottaa käyttämään ja laajentamaan kuvittelukykyä, jotta voimme ymmärtää tuotemaailman perustan ja merkityksen ihmisen ja muiden elollisten olemassaololle. Nykyisen tuotemaailman ontologian paljastamisen lisäksi kuvittelukykyä on kasvatettava, jotta voimme luoda tuotemaailmalle ja kilpailuyhteiskunnalle outoa olemisen ja olemassaolon perustaa.

Sivistysajattelun merkityksellisyys tuotemaailmassa on mielestämme kuvittelukyvyn käyttämisessä ja kasvattamisessa, jotta voimme yhä ymmärtää tämän ajan yksilöitä määrittäviä voimia. Todellisuuden toisin näkeminen on yksilölle keino nähdä myös itsensä toisin.

Yksilölle sivistyksen merkitys on yleisen ymmärtämisessä. Tällöin yksilö voi ymmärtää erilaisuutensa ja esittää kritiikkiä sitä kohtaan, joka on välttämätön osa myös häntä itseään. Vaikkapa omasta kansallisuudestaan voi tulla paremmin tietoiseksi muuttamalla joksikin aikaa toiseen maahan. Esimerkiksi suomalaiselle kansallisuus on välttämätön osa itseä, mutta hän voi oppia kriittisesti tarkastelemaan kansallisuuteen kuuluvia piirteitä.

Olemalla avoin toiseudelle ja yleisille näkökulmille yksilö kykenee ottamaan etäisyyttä itseensä, mikä mahdollistaa itsen tulkitsemisen toisen näkökulmasta. Yleinen näkökulma ei ole pysyvä mittapuu vaan tulkintakehys, jonka avulla yksilö voi ymmärtää itseään ja tunnistaa erityisyytensä. Yleisen näkökulman muodostaminen ja yksilön tulkitseminen sitä vasten edellyttää yksilöltä kykyä kuvitella yleinen ja itsensä yleisen näkökulmasta. Sivistys edellyttää yleisen näkökulman muodostamista ja samalla oman itsen ymmärtämistä osana yhteisöä, joka on yksilöksi kehittymisen kannalta välttämätön yleinen taso. Itsetuntemus on mahdollista vain kulttuurin ja yhteiskunnan tarkastelun avulla. (Gadamer 1990, 23.)

\section{TUOTEMAAILMAN METAFYYSINEN UMPIKUJA}

Ranskalainen matemaatikko Pierre-Simon Laplace (1902, 4) esitti vuonna 1814 Laplacen demoniksi nimetyn ajatuskokeen. Laplacen demoni on olento, joka tietää kaikki universumia hallitsevat luonnonlait ja luonnon muodostavien olioiden tarkat sijainnit. Demoni sisällyttää yhteen kaavaan olioiden pienimmätkin yksityiskohdat ja suurimpien kappaleiden liikkeet. Sille ei mikään ole epävarmaa, sillä sekä menneisyys että tulevaisuus ovat demonille jatkuvasti läsnä nykyisyydessä.

Laplacen demonin mahdollisuus tietää läpi ajan nykyisyydestä menneeseen ja tulevaisuuteen perustuu sen täydelliseen tietoon maailmasta ja sitä hallitsevista laeista. Demonin mahdollisuus nähdä tuleva ennalta olettaa välttämättömien syiden olemassaolon. Ihmisten tai muiden eliöiden vapauden kokemuksesta riippumatta maailma tapahtuu kuin se tapahtuu vääjäämättä. Mikään ei kykene vastustamaan välttämätöntä.

Tulkitsemme, että tuotemaailman olemassaolon oikeutus perustuu Laplacen demonin kaltaiseen näkymään todellisuuden perustasta. Tuotemaailmassa Laplacen demonin laskenta on manipulatiivista. Maailman manipuloiminen perustellaan välttämättömäksi kehityskuluksi. Se on ihmisen mielivaltaisia haluja palveleva ja samalla niitä alistava teknologia yhdistettynä 


\section{AinoA OIKEA}

\section{TULEVAISUUS VAATII}

\author{
TEKOJA, MUTTA \\ KIELT $\dddot{A} \ddot{A}$ TOIMINNAN.
}

pääoman kasvua tavoittelevaan talousjärjestelmään (Bunge 2007, 176). Tuotemaailman talousontologisen opin toteuttamisessa sekä materiaalinen että henkinen todellisuus nähdään raaka-aineina, joiden hyödyntäminen edellyttää teknologian käyttöä ja kehittämistä (Vrt. Anders 2002b, 25).

Andersin (2002b, 278-279) mukaan teknologiasta on tullut historian subjekti sinä määrin, että kykenemme vain odottamaan uutta teknologista uudistusta, joka johdattaa meidät seuraavaan aikaan. Samalla meistä tulee nykyisyyden vankeja; jähmetymme paikallemme tulevaisuuteen vaikuttamisen mahdollisuuksien kadotessa (Sennett 1998, 91). Toiminta suuntautuu tulevaisuuteen, joka osittain luodaan toiminnassa käytännöllisen järjen valintojen kautta. Jos päämäärä on toiminnan ulkopuolinen, puhutaan tekemisestä (Aristoteles 1140a, 31).

Ainoa oikea tulevaisuus vaatii tekoja, mutta kieltää toiminnan. Näin esimerkiksi filosofi VeliMatti Värrin $(2014,91)$ 'onkalometafysiikan ilmentymäksi’ nimeämä ydinjätteen hautapaikka, Onkalo, sitoo tulevatkin sukupolvet konkreettisesti Onkalon olemassaoloon ja sen edustamaan metafysiikkaan. Tuotemaailman talousontologia tuottaa vaihtoehdottomasti kuluttamiseen sidottua elämäntapaa, joka märiittää tulevien sukupolvien ajattelun ja toiminnan kaltaisekseen.

Tulevaisuuden kuvilla teknologisesta utopiasta (esim. LVM 2016, 55-56) oikeutetaan nykyhetken leikkaaminen irti menneestä ja nykyisen tuottaminen tulevaisuudeksi, mistä seuraa tietoteoreettisesti mielenkiintoinen perustelu: koska tulevaisuus tiedetään, nykyisyys on muutettava sen kaltaiseksi, sillä jos nykyisyys ei muutu tiedetyn tulevaisuuden kaltaiseksi, tulevaisuus muuttuu toisenlaiseksi. Yksiulotteisen metafysiikkansa ajamana tuotemaailma pyrkii ottamaan haltuunsa elämän - subjektien elämän ja elämän prosessit (McLaughlin 1993, 89-90).

Tuotemaailma manipuloi ihmisen kasvamista ja kehittymistä subjektiksi. Yhtäältä sen identiteettipolitiikka perustuu identiteettien näkemiseen erilaisina suoritusaihioina. Kun aiemmin riitti, että ihmiset samaistuivat ammatteihin ja halusivat olla merkonomeja, insinöörejä, opettajia ja laborantteja, nyt heidän tulee olla osaajia ja samaistua osaajiksi. Teknologisen edistyksen myötä tuotemaailma kuitenkin muuttaa perusteita, joilla osaajien - ja hyväksyttyjen - joukkoon kuulutaan. Samalla yhteisön ominaisuudet on siirretty yksilöön: ennen työttömyys oli yhteiskuntaperäinen ongelma, nyt se on yksilön kyvyttömyyden ongelma. Siten yksilö käy kamppailua osaajan ja häviäjän alati muutettavalla rajalla. (Ks. esim. Sennett 1998.)

Toisaalta tuotemaailmassa suunnataan ihmisen intentionaalisuutta, johon kuuluu tulevaisuuteen suuntautuneisuus. Laplacen demonin kaltaiseen näkymään vedoten vakuutetaan tiedettävän vääjämäättömästi saapuvan tulevaisuuden luonne. Yksilön osaksi jää muuntua tuotantoprosessin osaksi. Vapaus onkin tuotemaailmassa yhä enemmän vain kuluttamisen ja suorittamisen pakkoa. (Anders 2002b, 261.) Tuotemaailman metafysiikka on jähmettynyt magmaksi; siitä käsin muodostuu se psykososiaalinen todellisuus, jossa yksilöiden subjektiviteetti kasvaa ja muotoutuu.

Kilpailullisen tehokkuuden ajamana koneiden laskentateho kasvaa yhtä eksponentiaalisesti kuin se todennäköisyys, että tuotemaailma tulee aiheuttamaan elämänlaajuisen katastrofin (ks. WWF 2016). Tämä tosiasia tulisi demonin huomioida kaiken kattavassa yhtälössään. Ja kuitenkaan se ei ymmärtäisi oman tilansa mahdottomuutta; kaiken kattavan yhtälön tulisi sisältää kaiken kattava yhtälö, jonka edelleen tulisi sisältää kaiken kattava yhtälö, johon kuuluisi kaiken kattava yhtälö. Ja niin loputon rekursio on valmis.

Laplacen demoni ei voi koskaan saada yhtälöän suljettua. Vastaavasti tuotemaailmassa on yhä vaikeampaa sulkea ulkopuolelle ekologiset ja psykososiaaliset ongelmat, joita talousontologisen opin toteuttaminen luo. Tuosta tilasta käytämme nimitystä 'kilpailuyhteiskunnan metafyysinen umpikuja'. 


\section{AntiIkin filosofi Platon}

EROTTI TOISISTAAN

SIELUN J ̈̈RJELLISEN SEK $\ddot{A}$

HIMOITSEVAN JA KIIHKE ̈̈N

OSAN.

\section{KILPAILUYHTEISKUNNAN PSYKOSOSIAALINEN} UMPIKUJA JA AGGRESSIIVINEN TAHTO

Tuotemaailmaa toteuttavassa kilpailuyhteiskunnassa "Maamme kansainvälinen kilpailukyky vaatii sitä!" -lause on osa kilpailun oikeutusta ja retoriikkaa, jolla luodaan kuvaa globaalin talouseliitin ja kansan intressien yhdenmukaisuudesta (Rodrik 2016, 101). Kilpailuretoriikalla ihmisiä suostutellaan osaksi erityistä psykososiaalista toimintaa rajoittavaa järjestystä, jossa universaaliksi välttämättömyydeksi ymmärretty kilpailu on kuin pakottava luonnonlaki. Kilpailun eetoksessa luovuttaminen näyttää varhaiskristillisiin kuolemansynteihin verrattavalta paheelta, ja kilpailukyky ja kilpailunhalu keskeisiltä hyveiltä (Pulkki 2017).

"Älä koskaan luovuta" on kilpailuyhteiskunnan tunnuslause, joka tuo mukanaan kasvatuksellisia sivutuotteita. Sen omaksuminen elämänohjeeksi muuttaa ihmisen ajatuksia, tunteita ja motiiveja, joista muotoutuu tottumuksia ja luonteenpiirteitä. "Älä koskaan luovuta" -tunnuslauseen omaksuminen siis kasvattaa.

Filosofi Bertrand Russell (1872-1970) huomauttaa, että kilpailua, taistelua ja voittamista painottava katsomus johtaa "liialliseen tahdon viljelyyn aistien ja älyn kustannuksella”. Kilpailua painottavasta ihmisestä "rauhallinen, hermoja virkistävä joutilaisuus alkaa tuntua ikävystyttävältä”. Parannuskeino on se, että tasapainoiseen elämänihanteeseen liitetään "tervettä ja rauhallista elämän nautintoa”. (Russell 1952, 43-44.)

Russelin ajattelussa on ituja luovuttamisen etiikasta, jonka tarvetta ja merkitystä voidaan ymmärtää tarkastelemalla kilpailuyhteiskuntaan liittyvää aggressiivista tahtoa. Se ilmenee toimintana, jossa toisia ihmisiä pyritään haastamaan ja yllyttämään kilpailuihin, kamppailuihin ja väittelyihin piittaamatta toiminnan aiheuttamista haitoista. Kilpailuun liittyvää pyrintöä nousta toisten yläpuolelle ja alistaa näitä tappioon voidaan pitää aggressiivisena (Pulkki 2017).

Kasvatuksen ja aikuiskasvatuksen maailmassa aggressiivinen tahto ilmenee esimerkiksi koulujen rankinglistoina: "naming, shaming, and blaming". Hienotunteinen kasvattaja varjelee ihmisten yksityisasioita, jotta minuus voi kehittyä rauhassa (Virkkunen 1932, 384; Pulkki 2017, 176), mutta kilpailu asettaa ihmisten ja koulujen yksilölliset piirteet suorituskykyä ja tuotoksia arvottavan vertailun kohteeksi. Koulujärjestelmän ja siinä toimivien ihmisten on alistuttava laskelmiin koulujen tasosta. Samalla tulee hyväksyttäväksi ajatus kouluista koulutustuotteita tarjoavina palveluntuottajina tuotemaailmassa.

Russelin puhe tahdon ylikehittymisestä älyn ja aistien kustannuksella kuvaa aggressiivisen tahdon ongelmaa. Lannistumaton tahto on hyve, kun sitä käytetään eettisesti arvostettaviin tarkoituksiin ja kun sitä ohjaavat kypsä tunne-elämä ja järki. Mutta jo antiikin filosofi Platon erotti toisistaan sielun järjellisen sekä toisaalta himoitsevan ja kiihkeän osan. Hän painotti järjen kykyä tasapainottaa kiihkeyttä ja himoa, jotta hyveiden omaksuminen olisi helpompaa. Kehnoin ihmistyyppi Platonin mukaan on taistelunhaluinen ja kunnianhimoinen ihminen, jonka sielun järkiosa on vähemmän kehittynyt kuin sielun himoava ja kiihkeä osa. (Platon 1999, kirjat VII-VIII.)

Suunnitelmallinen toisen vahingoittaminen ei ole kilpailuissa kovin tavallista, mutta välinpitämättömyys toisen hyvinvointia kohtaan on. Adornon filosofiaa tutkinut Saila Anttonen $(1999,100)$ toteaa, että kovuuteen kasvaminen tarkoittaa samalla välinpitämättömyyden asenteen kehittymistä tuskan ja kärsimyksen tuottamista kohtaan. Kovuus ja ankaruus itseä kohtaan oikeuttavat muiden kohtelemisen samankaltaisesti (Adorno 2007). Kun kilpailussa toisia tuntevia olentoja kukistetaan ilman kiinnostusta näiden hyvinvoinnista, toimintaa voidaan pitää määritelmällisesti julmana. Julmuus tarkoittaa filosofi Timo Airaksisen $(1999,40)$ mukaan juuri välinpitämättömyyttä toisten kärsimyksestä, 
VAIN VOITTAJAT

VOIVAT SÄILYTT $\ddot{A}$

ERITYISYYTENS ̈̈.

jolloin toimintaa jatketaan aiheutetusta kärsimyksestä huolimatta.

Aggressiivisuus ilmenee selvästi tilanteissa, joissa subjekti kokee olevansa uhattu ja peloissaan. Kilpailuissa ihminen haluaa kilpailtua resurssia, jota ilman jääminen koetaan kielteiseksi. Ihmisyksilö tai -ryhmä pelkää, koska ryhmän osaksi tunnustaminen on suorituksilla ehdollistettu. Yksilöt voivat säilyttää erityisyytensä vain, jos he kuuluvat voittajiin. Silloinkin heidän on jatkuvasti varmistettava asemansa, jolloin heidän on omaksuttava kilpailuideologinen asenne itseensä, toisiin ihmisiin ja luontoon. Yksilöllisyyden ja yksilön olemassaolon hyväksyminen ainutlaatuisena, erityisenä olemisena on mahdotonta pelkän kilpailuideologian piirissä (Horkheimer 1997, 127).

Kilpailuideologinen asenne muuttaa (kasvattaa) ihmisten itseymmärrystä vaikuttaen minuuden rakentumisen ehtoihin, kuten taisteluun "tunnustuksesta" (ks. Honneth 1994). Kilpailussa yksilölle rakentuu aggressiivinen tahto, jonka perustella hän vaatii itselleen oikeuksia ja kavahtaa luovuttamista. Tuotemaailman talousontologiaa toteuttavassa kilpailuyhteiskunnassa arvokkuuden kokemus on ehdollistettu kilpailussa saavutettavalla tunnustuksella. Sitä saa lähinnä muita voittamalla, mutta voittajakin aavistaa, että ennen pitkää voiton ottaa joku toinen. Kilpailun logiikasta seuraa, että voittajia voi olla vain, jos enemmistö koostuu häviäjistä. Valtaosa kilpailijoista jää vaille minuuden rakentumisen kannalta tarpeellista tunnustusta.

Voittajien tunnustaminenkin perustuu mitattavaan suoritteeseen eikä esimerkiksi persoonan erityiseen arvokkuuteen, joka kuuluu kaikille persoonille. Kun erityislaatuisuutta ei tunnusteta, esimerkiksi ajattelu irrotetaan persoonasta mitattavaksi suoritteeksi. Varhaisen kriittisen teorian filosofien Horkheimerin ja Adornon mukaan ajattelu automatisoidaan, ja lopulta ihmisen ajattelu ajetaan kilpailemaan itse luomansa automatisoidun ajattelun eli koneälyn kanssa. Kilpailussa koneäly voittaa persoonasta lähtevän ajattelun. Samalla ajattelun merkitys typistyy kalkyylien tehokkaaksi suorittamiseksi. (Horkheimer \& Adorno 2008, 47.)

Psykososiaalisessa umpikujassa automatisoitunut ajattelu ei kykene tunnistamaan kuvittelukyvyn merkitystä todellisuuden hahmottamisessa (Taylor 1995, 64). Tuotemaailmaa ilmentävä kilpailuyhteiskunta päätyy psykososiaaliseen umpikujaan, jossa tunnustuksesta on tehty keinotekoisesti niukkaa (ks. Pulkki 2017, 42-45). Psykososiaalisesta umpikujasta on vaikeaa päästä pelkästään luovan kuvittelun avulla, koska tällöin pidättäydytään tuotemaailman magmoittuneessa perustassa. Radikaalin kuvittelun avulla voidaan sen sijaan esittää toisenlaista perustaa ihmisten olemiselle ja yhteiskunnan institutionalisoimiselle.

\section{LUOVUTTAMISEN NEGATIIVINEN DIALEKTIIKKA}

Adorno kavahti vallitsevalle järjestykselle vaihtoehtoisen eksaktin eettisen normiston tai arvoetiikan luomista, koska tuosta uudesta etiikasta täsmällisine normeineen muotoutuisi helposti uusi todellisuutta ja inhimillistä toimintaa alistava järjestys (Kotkavirta 1999).

Emme siten pyri kiteyttämään luovuttamisen etiikkaa uudeksi eettiseksi normistoksi, jonka pohjalta ihmisen toiminnan suunnan voisi määrätä. Sen sijaan esitämme luovuttamisen etiikan perustuvan myötätuntoon, vallitsevan järjestelmän kriittiseen tarkasteluun ja vaihtoehtoisen mutta järjellisen todellisuuskuvan hahmottamiseen. Tämän vuoksi pidämme tärkeänä Adornon Negatiivinen dialektiikka -teoksessa viitoittamaa polkua maailman hahmottamiseksi tavalla, joka ei pyri tyhjentävästi käsitteellistämään todellisuutta hallittaviksi identiteeteiksi.

Merkittävää on myös Andersin kehotus käyttää rohkeasti mielikuvitusta sen ymmärtämiseksi, 
IDENTITEETTI ON

ITSENS ̈̈ KÄSITT $\ddot{A M I S T A ̈ ~}$

SUHTEESSA ELETT $\ddot{A} V \ddot{A} \ddot{A} N$

AIKAAN JA SOSIAALISEEN

YMP ÄRISTÖÖN.

että vallitseva yhteiskunta ei ole ainoa eikä välttämätön maailma. Kasvatusajattelun näkökulmasta havainto on olennainen, jotta kasvatuksessa vaadittava spontaniteetin kunnioittaminen olisi mahdollista (Benner 2001, 80).

Teknologinen tulevaisuus vaatii meidät lunastamaan paikkamme kilpailussa, jossa tahdon on seurattava aggressiivista ahneutta. Jos emme kilpaile toisia häviäjiksi, joudumme häviäjiksi. Yksilön tehtäväksi jää muokata itsensä ulkoisten vaatimusten mukaiseksi, jotta hän voisi säilyä. Horkheimer ja Adorno $(2008,51)$ toteavat:

"Hänen mittanaan on itsesäilytys, se, onnistuuko hän muokkaamaan itsensä sellaiseksi kuin hänen tehtävänsä ulkoiset ehdot ja sille asetettu malli edellyttävät.”

Horkheimerin, Adornon ja Andersin analyysissä tuotemaailma määrittää yksilösubjektin lähes täydellisesti. Adornon luomaan negatiiviseen dialektiikkaan nojaten on kuitenkin hätiköityä hylätä subjektia, vaikka se näyttää määrittyvän ulkoisesti. Ulkoisista tekijöistä käsin määrittyvää yksilöä Adorno nimittää konstituoiduksi subjektiksi. Adorno (1975, 10) kirjoittaa Negatiivisen dialektiikan esipuheessa käyttävänsä subjektin voimaa rikkoakseen konstituoidun subjektiviteetin petoksen. Tuo petos on yksilön erityisyyden hävittämistä yksilöllisyyden nimissä. Yksilön valinnan vapaus pelkistyy tuotemaailmassa tuotettujen identiteettien vahvistamisena kuluttamisakteina. Irralliseksi yksilöksi määritetyn subjektin petoksen rikkomiseksi on ylitettävä perinteiset filosofian ja kokemusperäisten tieteiden rajat.
Subjektin konstituution petos on asetettava kritiikin kohteeksi tuotemaailmasta itsestään käsin. Voidaan esimerkiksi osoittaa tuotemaailman ajautuvan metafyysiseen ja psykososiaaliseen umpikujaan, kuten edellä on esitetty. On ikään kuin pelattava peliä, jossa kortit asetetaan pöydälle paljastamatta pelin luonnetta (mt., 9.)

Filosofian todellinen intressi on tällöin käsitteettömässä, yksittäisessä ja erityisessä. Tuotemaailma ei talousontologisen perustansa vuoksi kykene tunnistamaan erityisen ainutlaatuisuutta ja merkityksellisyyttä vailla hyödynnettävyyden ja tuotteistamisen näkökulmia. Konstituoidun subjektin petos on siten osoitettavissa radikaalin kuvittelukyvyn avulla viittaamalla subjektissa sellaisen olemassaoloon, jota ei talousontologisen opin mukaan ole lainkaan olemassa. Subjektin ainutlaatuinen oleminen osana muiden ainutlaatuisten eliöiden ja olioiden välisten suhteiden kokonaisuutta tulee tällöin tunnistetuksi.

Lisäksi on vielä purettava identifioinnin prosessi. Identifikaatio on sekä käsitteelliseen totaliteettiin pyrkivää ajattelua että subjektin samaistamista subjektia määrittäviin tekijöihin. (Mt., 22, 24.) Identiteetin rakentumisessa subjekti liittää itsensä osaksi jotain kokonaisuutta ja omaksuu samalla tuon kokonaisuuden perusolettamukset. Kehityspsykologi Homburger Erikssonin mukaan identiteetti on itsensä käsittämistä suhteessa elettävään aikaan ja sosiaaliseen ympäristöön. Identiteetillään subjekti jäsentää ja jäsentyy osaksi todellisuutta, josta välittyy subjektille merkityksellisen ja merkityksettömän luokittelu. (Jerlang 1994, 57-58.)

Identifioinnin kriittisen tarkastelun avulla on mahdollista ymmärtää ja arvostaa ei-identtisen olemassaolo. Ei-identtisen olemassaolon tunnistaminen voi johtaa sellaisen toiminnan välttämiseen, joka identifioi subjektin tekojensa tulokseksi. Näin esimerkiksi kilpailusta kieltäytyminen on kilpailun subjektia määrittävän pyrkimyksen väistämistä. Subjekti kykenee osoittamaan olevansa ei-identtinen kilpailullisen toiminnan kanssa. Samalla subjektin luovuttava toiminta tuo esiin todellisuuden relationaalisuuden, jossa erityinen voi tulla tunnustetuksi omana itsenään. 


\section{PIT $\ddot{A} \ddot{A}$ TUNNUSTAA}

\section{IHMISYKSILÖN ERITYISYYS}

SEN SIJAAN, ETT $\ddot{A}$ YKSILÖN

PIT $\ddot{A} \ddot{A}$ SOVITTAA ITSENS $\ddot{A}$

\section{KILPAILUYHTEISKUNNAN}

\section{MUOTTIIN.}

Subjektin on kuitenkin vältettävä yksittäisen ja erityisen käsitteellistämistä totaliteetin, tuotemaailman, käsittein. Subjektin on ymmärrettävä käsitteellistämisen vangitseva taipumus. Tietynlaiseksi käsitteellistetty ja luokiteltu olio tulee tunnustetuksi vain luokkansa edustajana eikä ainutlaatuisena ja erityisenä oliona, joka on osa moninaista erilaisten olioiden verkostoa. Esimerkiksi opettaja käsitteellistää opiskelijansa osittain heidän suoritustensa kautta. Olisi kuitenkin väärä yleistys nähdä opiskelija vain suoritustensa edustajana. Käsitteellistäminen on ymmärrettävä ennemminkin taideteoksen kaltaiseksi. Taideteoksen kyky kääntää käsitteellistämisen suunta käsitteellistämättömään osoittaa ei-identtiseen. Käsitteellistämisen suunnan muutos on välttämätöntä konstitutiivisten tekijöiden "totuuden" osoittamisessa epätotuudeksi. (Adorno 1975, 26-27.)

Adornon negatiivinen dialektiikka kehottaa meitä paljastamaan kokonaisuuden väkivaltaisuuden, koska kokonaisuus asettaa yksittäisen ja erityisen osaksi itseään sallimatta niiden ilmaista sitä, mikä niissä ei ole totaliteettia. Voittamisella tuotettu toiminnan merkityksellisyys ja sen tuottama identiteetti on kilpailuyhteiskunnan väkivallan logiikkaa, kun kilpailuyhteiskunta liittää itseensä yksittäisen huomioimatta yksittäisen erityislaatuisuutta.

Kilpailuyhteiskunta on tarjoavinaan yksilöllisiä mahdollisuuksia pakottamalla todellisuudessa kaikki lähtöviivalle huomioimatta jokaisen yksilön ainutlaatuista erityisyyttä. Näin sen julistama yksilöllisyys paljastuu valheeksi. Todellisuudessa yksilöistä muokataan pelkkiä saman lajin edustajia. (Horkheimer \& Adorno 2008, 61.) Sivistysajattelun näkökulmasta pitäisi tunnustaa ihmisyksilön erityisyys sen sijaan, että yksilön pitäisi muokata itsestään kilpailuyhteiskunnan yksilömallin sarjatuote.

Negatiivisen dialektiikan hengessä luovuttamisen etiikka on erityisen olemassaolon tunnustamisessa vailla sen vangitsemista. Tällöin luovuttamisen etiikka kääntyykin merkitykselliseksi, koska se sallii subjektin ja elollisen olennon erityisyyden. Tuotemaailman magma korostaa yksilön merkitystä ja samalla kuitenkin arvioi kaikkia kilpailijoita yksilön erityisyyttä tunnustamattomilla kriteereillä. Silloin se tosiasiallisesti kieltää yksilöllisyyden pakottamalla subjektin aggressiiviseen voiton ja menestyksen tavoitteluun. Kuten symbioosissa, luovuttaminen tuo esiin erityisyyden rikkautta pursuavan todellisuuden, joka ei perustu hävittämiseen vaan ylläpitämiseen. Ja ylläpitäminen edellyttää luovuttamisen moninaisuutta.

Adornolle sivistys sisältää vapauden ja humaanisuuden vaatimukset, joiden toteutuminen vaatii solidaarisuutta ja rakkautta (Anttonen 1999, 113). Yksilö, joka luovuttaa vailla kilpailuyhteiskunnan totaalisia käsitteitä, osoittaa kykenevänsä pelaamaan kilpailuasetelmalle vierasta peliä avoimin kortein. Kilpailuyhteiskunta ei pysty vailla oman perustansa radikaalia uudelleen arviointia selittämään luovuttamisen etiikan tunnustamaa erityistä, ja siten se alkaa näyttää kammottavalta ja huvittavalta. Tuotemaailman raja on metafyysisestä ja psykososiaalisesta umpikujasta johtuen kyvyttömyydessä ymmärtää luovuttaminen harkittuna ja aktiivisena päätöksenä, jota motivoivat solidaarisuus ja rakkaus.

Voittoja kyltymättömästi janoavassa yhteiskunnassa tuotemaailma pyrkii kuitenkin saattamaan identifioivaan myllyynsä nekin, jotka harkiten luovuttavat. Joka tapauksessa identtisen ja ei-identtisen välissä on ei-identtinen, jonka tunnistaminen ja tunnustaminen on luovuttamisen alku. Esimerkiksi vapauden määritteleminen valinnaksi annetuista vaihtoehdoista pitää kuitenkin sisällään määritelmän eiidenttisyyden suhteessa kysymykseen; mitä vapaus on. Ei-identtisen tunnustaminen osoittaa vapauden mahdollisuuteen vailla pyrkimystä kaventaa vapauden merkitystä pelkiksi valinnoiksi. 
IHMISEN TUOTANTOKYKY

\author{
ON YLITTÄNYT \\ HÄNEN KUVITTELU- JA
}

TUNNEKYKYNSÄ.

\section{SUUNTAUTUMINEN POIS TUOTEMAAILMASTA}

Günther Andersin tuotemaailman analyysin mukaan ihmisen tuotantokyky on ylittänyt hänen kuvittelu- ja tunnekykynsä (Anders 2002a; Jokisaari 2004). Olemme yhä vähemmän tietoisia toimintamme sisällöstä tai työmme tuloksista. Ihmisen maailmallisuuden muuttuminen tuotemaailmaksi on muokannut olennaisen ja epäolennaisen luokat uusiksi. Siten alamme pitää ilmentymiä olennaisena ja olennaista ilmentyminä. Esimerkiksi yliopistot ansaitsevat rahoitusta, jos ne tuottavat markkinoitavia tuotteita koulutuspaketeista kulutustuotteisiin. Tieto on tuon toiminnan ilmentymää ja sinänsä epäolennaista tuotemaailmassa.

Sen sijaan, että keskitymme tuotemaailmaan Anders (2002a, 273) kehottaa meitä käyttämään ja laajentamaan kuvittelukykyä. Hänelle kuvittelukyvyn kasvattaminen on pedagoginen prosessi (Jokisaari 2017). Meidän tulee kyetä kuvittelemaan elämää tuotemaailman tälle puolen. Jos osoitamme tuotemaailman olennaisen luokittelut ongelmallisiksi, ei-identtisen ainutlaatuisuus ja erityisyys on mahdollista havaita ja tunnustaa. Identifikaatio tuotteisiin on tällöin mahdollista purkaa ja päästää irti niistä merkityssuhteista, joita tuoteidentifikaatio on synnyttänyt. Tällöin sivistys toteutuu emansipatorisesti, kun yksilö ymmärtää erityisyytensä toiseuden näkökulmasta. Samalla hän käsittää olemisensa relationaalisuuden suhteessa toisiin ihmisiin, eliöihin ja ekosysteemeihin.

Kun elämä tunnustetaan itsenäiseksi hyvän kategoriaksi, sen arvokkuuden kilpailullinen tuotteistaminen näyttäytyy irvokkaana. Näin voimme ymmärtää, miksi luovuttaminen on rationaalinen toimintamalli. Rationaaliseen elämään kuuluvat keskittyminen olennaiseen, suhteellisuudentaju ja kohtuullisuus. Kun tuotemaailmassa epäolennainen työntyy olennaisen tilalle, sokaistumisyhteys on valaistava radikaalin kuvittelun avulla. Harkitun toiminnan mukaisesti luovuttaminen on olennainen osa hyvään elämään pyrkimystä.

Filosofi John Sallis (2000) määrittää kuvittelukyvyn osaksi maailmallisuuttamme, osaksi sitä mitä voidaan kutsua elementaariseksi - maa, vesi, ilma. Identifioivan ajattelun seurauksena olemme ryhtyneet selittämään eliöyksilöiden olemassaoloa luonnonvoimilla ohittaen eliöiden erityisyyden. Tämä on johtanut luonnon identifioimiseen varastoksi, raakaaineeksi ja ylimääräksi. Se, mikä on jänyt tuon selityksen ulkopuolelle, on siirretty mystismin tai irrationaalisen haihattelun kohteeksi. Tuo ei-identtinen, esimerkiksi elollisuus, on kuitenkin olemassa ja sen olemassaolo on elementaarista ihmisenä olemisen rationaalisuudelle. Tässä mielessä rationaalinen toiminta ottaa huomioon paikan, ajan, elollisuuden, tunteet, vuorovaikutuksen ja ylipäätään sen, mitä kuuluu maailmallisuuteen. (Mt. 149-150.)

Luovuttamisen ajatuksen näkökulmasta kuvittelukyky on välittömästi läsnä, kun kohtaamme toisen elollisen olennon, sillä paradoksaalisesti meitä yhdistävät elollisena olemisen samuus ja eliöyksilöinä olemisen erityisyys. Luovuttamisen etiikan mukaan ihmisille on tärkeää käsitteellistää tuo kokemus eiidenttisen säilyttävänä. Luovuttaminen on tässä mielessä suuntautumista todellisuudessa, jossa erityisyyden rikkauden ymmärtäminen ja huomioiminen on olennaista toiminnan eettisyyden kannalta. Erityisyyden rikkauden avulla yksilö kykenee sivistysajattelun periaatteen mukaisesti ymmärtämään itsensä moninaisuuden ja erityisyyden osana muita.

\section{POHDINTA}

Adorno $(1997,7)$ kirjoittaa Minima Moralia -teoksessaan filosofiasta, joka pyrkii muodostamaan opin oikeasta elämästä. Nyt tuo elämä itsessään on romahtanut pakkokulutuksen piiriin, jossa objektiiviset voimat määrittävät yksilön elämän sisällön ja suunnan. 


\section{K ̈̈YTÄNNÖLLINEN JÄRKEVYYS}

\section{TARKOITTAA HYVEET}

\author{
HUOMIOIVAA POHDINTAA ERI \\ VAIHTOEHTOJEN V ̈̈LILL ̈̈.
}

Luovuttamisen etiikan näkökulmasta on perusteltua katsoa, mitä oikea elämä on joskus tarkoittanut. Ensinnäkin päämääräsuuntautuneisuus on ihmisen toiminnalle ominaista. Ihmisen toimintaa on mahdoton ymmärtää ilman että viitataan hänen käsityksiinsä tulevasta. Aristoteles perustaa päämääräsuuntautuneisuuteen Nikomakhoksen etiikassa esitetyn hyvän elämän mallinsa. Hyve-etiikaksi nimetyn opin mukaan ihmisen tulisi suuntautua kohti onnellista elämää, joka olisi parasta ihmisen elämää. Onnellisen elämän toteutuminen riippuu olennaisesti niistä hyveistä, joihin kasvamme. Lisäksi meillä täytyy olla kyky käytännölliseen harkintaan, fronesikseen.

Harkitsevassa toiminnassa teemme hyveiden suuntaamina ratkaisuja, joiden ymmärrämme vaikuttavan elämänkaaren muodostumisen laatuun. Käytännöllinen järkevyys tarkoittaa hyveet huomioivaa pohdintaa eri vaihtoehtojen välillä. (Aristoteles 1140a-1141b.)

Ihmisen toiminta on aina suuntautunut johonkin. Lisäksi ihmisenä olemiseen kuuluu maailmallisuus, joka tarkoittaa aina jossakin mukana olemista (Heidegger 1993, 132). Yksilökin omassa yksilöllisyydessään on aina maailmallinen olento. Asiat, joihin suuntaudumme, täyttävät tietoisuutemme. Ja tietoisuutemme täytteet näyttävät, mihin elämämme suuntautuu. Tämän tietävät varsinkin markkinointiosastot. Suuntautumisemme määrittyy sen mukaan, mitä olemme oppineet pitämään olennaisena erotuksena epäolennaisesta. Koska tietoisuutemme ei voi suuntautua kaikkeen maailman moninaisuudessa, haluamme suuntautua olennaisen luokkaan kuuluviin kohteisiin.

Suuntautuneisuus tuo esiin luovuttamisen etiikkaan kuuluvan ajatuksen, jonka mukaan luovuttaminen on aina luovuttamista johonkin. Kun luovutan jotain itsestäni, joku toinen tai muu saa jotain. Samalla tuo toinen on yhteydessä itseeni, eikä luovuttaminen tässä mielessä vaadi uhrimieltä tai sankarillisia omaa hyvinvointia estäviä tekoja.

Luovuttaminen toimintana tuo esiin olioiden olemuksellisen monimuotoisen ja -mutkaisen liittyneisyyden toisiinsa. Esimerkiksi metsänomistaja voi metsän taloudellisen hyödyn sijaan ymmärtää metsän merkityksen monien olioiden hyvinvoinnin ja elämän lähteenä. Verenluovuttaja ymmärtää olevansa elämän ylläpitäjä. Luovuttaminen voi olla tie muuttaa yhteiskuntien magma vastaamaan ekososiaalisesti kestävän yhteiskunnan vaatimuksia. Yhteisöllinen yksilöllisyys on merkityksellistä, kun yksilölle hahmottuu toisiinsa liittyneiden olioiden todellisuus. Yhteisöllinen yksilöllisyys on läheisesti yhteydessä sosiaalisen vapauden ajatuksen kanssa. Sosiaalinen vapaus korostaa yhteisöllisten ja yhteiskunnallisten tekijöiden merkitystä yksilöksi kehittymisen ja yksilön päämäärien toteutumisen kannalta (Honneth 2017, 52).

Luovuttamisen etiikassa erityisyyden yhteen kietoutunut olemassaolo nousee olennaisen luokkaan, jolloin ihmisyhteisöjen suuntautuminen muuttuu erityisyyden huomioivaksi.

Kasvatus- ja sivistysajattelun näkökulmasta luovuttamisen etiikka vaatii kuvittelukyvyn ymmärtämistä ja radikaalin kuvittelukyvyn käyttämistä. Se, miten maailman ja erilaisten olioiden oleminen hahmotetaan, vaikuttaa minuuden käsittämiseen suhteessa aikaan ja paikkaan. Ja edelleen se, miten hahmotamme itsemme ympäristössä, on ratkaisevaa eettiselle toiminnalle. Tarinoiden, vertauskuvien ja symbolisen tajunnan kehittäminen on siten tärkeä osa kasvatuksellista toimintaa. (Levad 2011, 71.)

Luovuttamisen etiikan näkökulmasta olisikin hahmotettava vaihtoehtoisia narratiiveja, joissa radikaalia kuvittelukykyä käyttäen vallitsevan yhteiskunnan magmaa rikotaan ja sulatetaan uudelleen muokattavaksi. Tällöin luovuttamisen etiikan narratiiveissa tulisi ymmärrettäväksi esimerkiksi ekososiaalinen sivistyksen merkitys.

Aristoteelinen harkinta kehottaakin luovuttamaan, kun vaihtoehto olisi elämän kokonaisuuden kannalta huono toimintatapa. Selviä esimerkkejä ovat riippuvuudet ja maapallon kantokyvyn ylittävä 
LUOVUTTAMISEN ETIIKKAAN

PERUSTUVA ELÄMÄNTAPA

KEHOTTAA IHMISI $\ddot{A}$

YMM ̈̈RT ̈̈M ̈̈̈N KESKIN ̈̈ISI $\ddot{A}$

RIIPPUVUUKSIA.

kulutus. Harkittuun elämäntapaan ei kuulu osallistuminen sellaiseen yleistä ihailuakin aiheuttavaan kilpailutoimintaan, joka on elämälle haitallista. Tässä merkityksessä luovuttaminen on harkitsevan toiminnan hyveiden ja arvojen kunnioittamista. Hyve-etiikan näkökulmasta luovuttaminen edellyttää todellisuuden hahmottamista ja toimintaa identifioimatta todellisuutta saman toistoksi, jota voisi manipuloida halujensa mukaan. Luovuttamisen motivaatio vahvistuu toiminnan merkityksellisyyden kokemisessa, mikä lisää rohkeutta, päättäväisyyttä ja halua irtautua haitallisesta toiminnasta. Tuotemaailmaan sidottu välineellinen järki oikeuttaa itsensä alistamalla olemisen välinepäämäärä-totaliteettiin; luovuttamisen etiikka painottaa viisautta pysähtyä pohtimaan tuon mallin ja alistamisen mielekkyyttä.

Luonnostelemamme luovuttamisen etiikka on kilpailemiseen ja aggressiiviseen tahtoon nähden toisenlainen ajatus- ja toimintamalli, johon kuuluu olennaisesti kyky kuvitella olemista kilpailuyhteiskunnan ja tappiomielialan eli defaitismin tuolle puolen. Kilpailemiseen ja aggressiiviseen tahtoon liittyvä defaitismi lähtee alemmuuden ja ylemmyyden dialektiikasta sekä hierarkkisesta ajattelusta. Luovuttamisen etiikassa todellisuus on pikemminkin erilaisten luovutussuhteiden rihmastomainen verkosto. Siinä huomioidaan olioiden ja eliöiden moninaisuus ja erityisyys. Kilpailutotaliteetin sijaan luovuttamisen etiikan ydin onkin yhteissidonnaisuus, joka nähdään myös ekologisena monenlaisten eliöiden yhteistyönä, resurssien jakamisen mahdollisuutena ja välttämättömyytenä eriarvoistumista ja luonnon tuhoamista vastaan.
Defaitismi on luovuttamisen hyveiden näkökulmasta passiivista ja pienisieluista alistumista kilpailuun ja taistelun pakkoon. Luovuttamisen etiikkaa kuvaavat 'lahjoittavat hyveet', kuten anteliaisuus ja jalomielisyys, jotka tuovat esiin erityisyyden kauneuden vangitsemattomuudessaan. Jos kilpailutoiminnassa fokus on oman intressin toteutumisessa, luovuttamisen etiikka osoittaa erilaisten intressien mutualismiin. Maailmankuulun ympäristöaktivistin Vandana Shivan (2010, 13-16) sekä runoilija, kirjailija ja filosofi Wendell Berryn (1987, 54-75) ajattelussa korostuu, että ihminen ei organisoi talouttaan eli tarpeiden tyydytystä erillään muista elävistä olennoista vaan aina näiden kanssa. Luovuttamisen ja vastaanottamisen aineenvaihduntaprosessit kuuluvat "olemassaolon suureen järjestykseen" (mt.), josta ihmisenkin toimeentulo riippuu.

Luovuttamisen etiikkaan perustuva elämäntapa ei ole vallitsevan kilpailuyhteiskunnan politiikan edestä väistymistä. Se kehottaa ihmisiä ymmärtämään, että he ovat riippuvaisia toisistaan ja muiden elollisten olemassaolosta. Ilman luovuttamisen moninaisia prosesseja ei ihmisen elämää voisi olla. Tämä olisi käsitettävä myös politiikan normatiiviseksi ohjeeksi. (Taylor 1986, 103.) Ihmisen hyvinvointia ei voi olla olemassa ekokriisien ja sosiaalisen eriarvoisuuden maailmassa. Vastaavasti politiikka, joka lisää sosiaalista ja taloudellista eriarvoisuutta asettamalla yksilöt toisiaan vastaan, lisää pahoinvointia. Yhteiskunnallinen pahoinvointi vaikeuttaa keskinäisen riippuvuuden käsittämistä yhteiskunnan yhdeksi perustaksi, mikä asettaa lopulta yhteiskuntarauhan kyseenalaiseksi. Luovuttamisen etiikkaan perustuva politiikka ei ole yksittäisten ja toisilleen vastakkaisten etujen törmäyskenttä. Sen sijaan politiikka on käsitettävä yhteiskunnan sosiaalisesta ja ekologisesta perustasta käsin.

Kilpailun viitekehys kumpuaa politiikan filosofi Crawford Macphersonin (1961) ajatuksia seuraten omistamiseen identifioituvasta 'possessiivisesta individualismista', jonka edellytyksenä on ihmisen samaistuminen omistuksensa kohteisiin. Luovuttamisen etiikan kasvatuskäsitys on ekososiaalista sivistystä, jota ohjaavat rakkauden ja solidaarisuuden tunteet. Siten se liittyy moraalisen huomioimisen hyveisiin: hyväntahtoisuuteen, myötätuntoon, sympatiaan ja huolenpitoon (Taylor 1986, 212). 
KASVATUKSESSA ON

JOKAISELLA OLTAVA TILAA

LUODA MERKITYKSIÄ OMASTA ERITYISYYDEST ÄÄN KÄSIN.

Kasvatuksessa on jokaisella oltava tilaa luoda merkityksiä omasta erityisyydestään käsin. Koska harkinta perustuu aina myös kuvittelukykyyn, on mahdollista nähdä tulevaisuus, joka voi olla radikaalilla tavalla toisin.

Luovuttamisen etiikka edellyttää hyvinvoinnin käsitteen laajentamista vastaamaan ekologista ja sosiaalista todellisuutta. Hyvinvointia ei voi olla ekologisen ja sosiaalisen katastrofin maailmassa, kuten ekososiaalisessa sivistysajattelussakin (Salonen \& Bardy 2015) painotetaan.

Luovuttamisen etiikan harjoittaminen vaatii aktiivista osallistumista ja vaikuttamista yhteiskunnan magman muuttamiseksi. Luovuttamisen etiikkaa on toiminta, joka kyseenalaistaa näkemyksen elämästä kilpailukenttänä ja pyrkii estämään maailman jakamisen voittajiin ja alistettaviin. Sen harjoittaminen ja radikaaliin kuvittelukykyyn luottaminen yhä useamman ihmisen yhteisessä toiminnassa johtaa uudenlaiseen sosiaalisten merkitysten verkoston luomiseen, mikä edelleen vaikuttaa tuotemaailman ontologiaan perustuvien yhteiskuntien muuttumiseen.

Ensimmäistä kertaa luovuttamisen etiikkaa pohjustavassa artikkelissa ei voida kuitenkaan tarkkaan osoittaa polkuja kohti maailmaa, jossa toivon tunteiden sävyttämät kaipaukset paremmasta maailmasta voisivat täyttyä. Kriittinen keskustelu ja toiminta lopulta ratkaisevat, mitä luovuttamisen etiikasta seuraa.

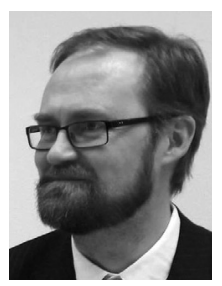

OLLI-JUKKA JOKISAARI

FT, psykologian ja filosofian lehtori

Turun kaupungin opetustoimi

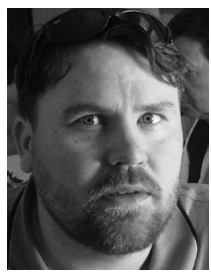

PULKK

KT, tutkija

\section{LÄHTEET}

Aaltola, E. \& Keto, S. (2017). Empatia: myötäelämisen tiede. Helsinki: Into kustannus.

Adorno, T. (1975). Negative Dialektik. Frankfurt am Main: Suhrkamp.

Adorno, T. (1997). Minima Moralia. Frankfurt am Main: Suhrkamp.

Adorno, T. (2001). Zur Lehre von der Geschichte und von der Freiheit. Nachgelassene Schriften Bd. 13 (Hrsg.) Rolf Tiedemann. Frankfurt a. M: Suhrkamp.

Adorno, T. (2007). Kasvatus Auschwitzin jälkeen. Teoksessa Koivisto, J. \& Mäki, M. \& Uusitupa, T.(toim.) Mitä on valistus? Tampere: Vastapaino, 222-240.
Anders, G. (2002a). Die Antiquiertheit des Menschen 1: Über die Seele im Zeitalter der zweiten industriellen revolution. München: $\mathrm{C}$. H. Beck.

Anders, G. (2002b). Die Antiquiertheit des Menschen 2: Über die Zerstörung des Lebens im Zeitalter der dritten industriellen revolution. München: C. H. Beck.

Anders, G. (2002c). Wir Eichmannsöhne. Offener Brief an Klaus Eichmann. München: C. H. Beck.

Anttonen, S. (1999). Kasvatus, sivistys ja yhteiskunta: Kriittisen teorian sivistysdiskursseja. Teoksessa Moisio, O.-P. (toim.) Kritiikin lupaus: Näkökulmia Frankfurtin koulun kriittiseen teoriaan. Sophi: Jyväskylä. 95-125. 
Aristoteles (1989). Nikomakhoksen etiikka. Suom. Simo Knuuttila. Gaudeamus: Helsinki.

Benner, D. (2001). Allgemeine Pädagogik. Eine systematisch-problem-geschichtliche Einführung in die Grundstruktur pädagogischen Denkens und Handelns. Weinheim / München: Juventa.

Berry, W. (1987). Home economics. Fourteen Essays by Wendell Berry. San Fransisco: North Point Press.

Bunge, M. (2007). Philosophical Inputs and Outputs of Technology. Teoksessa Scharff, R. C. \& Dusek, V. (toim.) Philosophy of Technology: The technological Condition: An Anthology. Blackwell Publishing, 172-181.

Castoriadis, C. (1997). World in Fragments: Writings on Politics, Society, Psychoanalysis, and the Imagination. Käänt. ja toim. Curtis, D. A. California: Stanford University Press.

Envall, M. (2010). Polkupyörällä ajamisen taito ja muita esseitä. Helsinki: WSOY.

Gadamer, H.-G. (1990). Hermeneutik I: Wahrheit und Methode. Gesammelte Werke I. Tübingen: MohrSiebeck.

Heidegger, M. (1993). Sein und Zeit. Tübingen: Max Niemayer Verlag.

Honneth, A. (2017). Die Idee des Sozialimus. Berlin: Suhrkamp Verlag.

Horkheimer, M. \& Adorno, T. (2008). Valistuksen dialektiikka: Filosofisia sirpaleita. Suom. Veikko Pietilä. Tampere: Vastapaino.

Jerlang, E. (1994). Erik Homburg Erikssons psykoanalytiska teori. Jerlang E. (red.) Utvecklingspsykologiska teorier. Liber Utbilding. Scandinavian University Books. Berlings, Arlöv.

Jokisaari, O.-J. (2004). Elinkäinen oppiminen - häpeä ja menetetty vapaus. Aikuiskasvatus 24 (1), 4-16.

Jokisaari, O.-J. (2017). Kasvatus tuotemaailmassa - Günther Anders kasvatusfilosofina. Acta Universitatis Tamperensis 2268. http://urn.fi/ URN:ISBN:978-952-03-0403-4. Tampere: Tampere University Press.

Kotkavirta, J. (1999). Omantunnon huono omatunto: Adorno, etiikka ja negatiivinen moraalifilosofia. Teoksessa Moisio, O.-P. (toim.) Kritiikin lupaus: Näkökulmia Frankfurtin koulun kriittiseen teoriaan. Sophi: Jyväskylä, 157-176.

Laplace, P. S. (1902). A Philosophical Essay on Probabilities. Käänt. Truscott F.W. \& Emory F.L. New York: John Wiley \& Sons. https://archive.org/details/ philosophicaless00lapliala (9.5.2017).

Levad, A. (2011). Criminal Justice: Recent Scholarship: Restorative Justice : Theories and Practices of Moral Imagination (1). El Paso, US: LFB Scholarly Publishing LLC. ProQuest ebrary.
LVM (2016). Robotiikan taustaselvityksiä. Liikenne- ja viestintäministeriö. 2/2016.

McLaughlin, A. (1993). Regarding Nature: Industrialism and Deep Ecology. Albany: SUNY.

Macpherson, C. B. (1961). The political theory of possessive individualism. Hobbes to Locke. Oxford University Press.

Nancy, J.-L. (2007). The Creation of the World, or, Globalization. Käänt. Raffoul, F. \& Pettigrew, D. Albany: SUNY.

Ojakangas, M. (1997). Lapsuus ja auktoriteetti. Helsinki: Tutkijaliitto.

Platon (1999). Valtio. Suom. Marja Itkonen-Kaila. Helsinki: Otava.

Pulkki, J. (2017). Kilpailun kasvatuksellisista ongelmista. Hyveitä 2000-luvulle. Acta Universitatis Tamperensis 2332. Tampere: Tampere University Press.

Russell, B. (1952). Onnen valloittaminen. Jyväskylä: Gummerus

Sallis, J. (2000). Force of Imagination: The Sense of the Elemental. Bloomington and Indianapolis: Indiana University Press.

Salonen, A. \& Bardy, M. (2015). Ekososiaalinen sivistys herättää luottamusta tulevaisuuteen. Aikuiskasvatus 35 (1).

Salonen, A. (2018). Ekososiaalinen sivistys - mitä se on? https://artosalonen.com/ekososiaalinen-sivistys-mitase-on/ (9.8.2018), 4-15

Shiva, W. (2010). Earth democracy. Justice, sustainability, and peace. New Delhi: Natraj Publishers, Dehradun.

Skillings, D. (2017). Life is not easily bounded. aeon co. https://aeon.co/essays/what-constitutes-anindividual-organism-in-biology (3.1.2018).

Taylor, C. (1995). Philosophical Arguments. Cambridge / London: Harvard University Press.

Taylor, P. W. (1989). Respect for Nature: A Theory of Environmental Ethics. Princeton: Princeton University Press.

Virkkunen, P. (1932). (toim.) Kasvatus. Aakkosellinen tietokirja kotia, koulua ja yhteiskuntaa varten. Ensimmäinen osa. Helsinki: Otava.

von Wright, G. H. (1999). Tieto ja ymmärrys. Helsinki: Otava.

Värri, V.-M. (2014). Halun kultivointi ekologisen sivistyksen mahdollisuutena. Teoksessa Saari, A \& Jokisaari, O.-J. \& Värri, V. M. Ajan kasvatus: Kasvatusfilosofia aikalaiskritiikkinä. Tampere: Tampere University Press, 87-122.

WWF (2016). Living Planet Report 2016. Risk and resilience in a new era. http://wwf.panda.org/about_ our_earth/all_publications/lpr_2016 (3.1.2018). 